Article

\title{
Current Advances in Seed Orchard Layouts: Two Case Studies in Conifers
}

\author{
Kateřina Chaloupková ${ }^{1, *}$, Jan Stejskal ${ }^{1}$, Yousry A. El-Kassaby ${ }^{2}$, John Frampton ${ }^{3}$ \\ and Milan Lstibuirek ${ }^{1}$ \\ 1 Department of Genetics and Physiology of Forest Trees, Faculty of Forestry and Wood Sciences, \\ Czech University of Life Sciences Prague, Kamýcká 129, 16521 Prague 6, Czech Republic; \\ stejskalj@fld.czu.cz (J.S.); lstiburek@fld.czu.cz (M.L.) \\ 2 Department of Forest and Conservation Sciences, Faculty of Forestry, University of British Columbia, \\ 2424 Main Mall, Vancouver, BC V6T 1Z4, Canada; y.el-kassaby@ubc.ca \\ 3 Department of Forestry and Environmental Resources, College of Natural Resources, North Carolina State \\ University, 3219 Jordan Hall, Raleigh, NC 27695-8002, USA; john_frampton@ncsu.edu \\ * Correspondence: chaloupkovak@fld.czu.cz; Tel.: +420-728-513-742
}

Received: 19 December 2018; Accepted: 23 January 2019; Published: 24 January 2019

check for updates

\begin{abstract}
Currently, there has been an increasing demand on seed orchard designs with respect to mitigating inbreeding in advanced generations or facing severe mortality at sites. Optimum Neighborhood Algorithm design (ONA) excels in solving these issues, as shown in two case studies. The first demonstrates the application of the ONA for populating empty positions in an existing orchard. Following this concept, the ONA can be used for upgrading existing orchards, where only high-value parents are retained and new parents are introduced, thus avoiding the genetic penalty associated with the establishment of new-generation seed orchards. The second illustrates benefits of combining the ONA with the Minimum Inbreeding (MI) seed orchard design. Utilizing the MI, distances among clonal rows of selected clones were maximized on the orchard grid while the remaining single-tree positions were populated by ONA.
\end{abstract}

Keywords: optimum neighborhood algorithm design; minimum inbreeding design; orchard upgrading; spatial arrangements; clonal rows; panmixia

\section{Introduction}

The main task of seed orchards is to ensure the production of abundant and frequently harvested genetic-quality seed for reforestation, without scarifying genetic gain and diversity [1]. Clonal orchards are the most common type, as they secure the transmission of the selected genes to the seed crops [2]. For cost saving and management ease, seed orchards are generally wind-pollinated. Therefore, the location of individual clones' members in the orchard's grid is one of the main factors affecting the mating pattern and the quality of the resulting seed yield [3]. The main requirement for clonal seed orchard design is to maintain adequate distance among relatives and ramets of the same clone to avoid inbreeding and supporting panmixia. In an effort to meet these demands, most seed orchard designs assume that the most frequent genetic exchange occurs among close neighbors [4].

For several decades, computer-based algorithms have been commonly used for developing seed orchard layouts. One of the most frequently employed programs is the Computer Organized Orchard Layout (COOL), as it systematically maintains predetermined separation distance among clonal ramets [5,6]. Separation among clonal ramets becomes more complicated in advanced-generation seed orchards where the inclusion of related parents is often practiced. To overcome this limitation, the Minimum Inbreeding seed orchard design (MI) was developed [7]. 
A specific group of seed orchard designs was developed implementing clonal rows, mainly to simplify crop management (e.g., supplemental mass pollination, cone harvest, pest control), cost reduction, and maximize genetic efficiency [8-10]. The clonal row concept was adopted as selfing seems to be negligible [8,9], and some studies highlighted its rather low rate in seed orchards [11-13]. In most conifers, the observed low selfing rate is not surprising considering the high genetic load, inbreeding depression, and unique reproductive biology such as polyembryony [14-16]. The main disadvantage of these designs is the neighborhood effect that occurs betweenrows. This neighboring effect results in increased correlated paternity [8,9], resulting in violating thepanmixia requirement in cases of open pollination management. This problem was partly solved by the Randomized, Replicated, Staggered Clonal Row design ( $\mathrm{R}^{2} \mathrm{SCR}$ ) [10]; however, selective pollination and selective seed harvesting can be mostly conducted only for superior clones, so it is not necessary to allocate all clones as clonal rows. In this specific case, it is more feasible to use an approach combining attributes of the MI [7] and the Optimum Neighborhood Algorithm (ONA) [17] designs, which is presented further in the second case study (establishment of the Douglas fir seed orchard).

Currently, there is no available design that allows the improvement of an existing orchard often affected by mortality (due to the rootstock incompatibility, diseases, and pests), which further affects the orchard production capacity. Moreover, there is no tool for improving existing orchards by adding superior individuals after a genetic thinning. In both cases, it is possible to use the ONA as presented here in the first case study, where it was used for a current European silver fir (Abies alba Mill) seed orchard restoration.

In both presented case studies, we capitalize on the advantages of ONA and MI compared to other designs $[7,17]$ from the point of view of minimizing inbreeding and maximizing panmixia. In the second case study, we tested the emerging possibility of combining both algorithms (i.e., ONA and MI). Both designs can be used in situations where an irregular orchard grid of any shape or size and under balanced or unbalanced clonal size exists, which is an important condition as it capitalizes on the possibility of combining both algorithms $[17,18]$.

\section{Materials and Methods}

The MI design is based on the industrial concept of "Quadratic Assignment Problem (QAP)", with input parameters provided within the C-matrix (intensity of separation between individuals) and the D-matrix (distances among all positions). Therefore, the spatial distribution among individual trees is a function of their genetic relatedness extent. The main advantage of the MI design is maximizing the distance among ramets of related clones, which makes it an optimal tool for establishing advanced-generation seed orchards [18]. Second, the QAP global optimization attributes are unique in comparison to the existing layouts (local search algorithms). The recently introduced ONA design is primarily focused on supporting panmixia by optimizing the number of direct neighborhoods among all present clones (probability of pollination among all clones is more or less the same). A panmictic mating pattern is ensured by minimizing close neighborhoods variation among all present clones. A desired state (i.e., the same number of close neighborhoods among all clones) can be attained within the population of the orchard grid following sequential complex evaluation of every possibility through the iterative form of the algorithm. Moreover, ONA can be further combined with other designs because it can easily populate predefined schemes. In these cases, all neighborhoods with occupied positions are considered in the input scheme and are included in the optimization. This became possible through the direct implementation within the algorithm, and thus it became feasible to use the ONA for the improvement of existing orchards [17].

The functionality of the ONA is based on maximizing panmixia by optimizing the size of the neighborhood using the parameter $\sigma_{\min }^{2}$ (variance in the number of direct neighbors among all clones) [17]. Contrastingly, the functionality of the MI design is based on maximizing the distance between the selected clones using the parameter $d_{\min }$ (represents the inverse sum of squares of all 
possible distances between any two ramets of the same clone and across all clones) [18]. The parameter $\sigma_{\min }^{2}$ is used for the resulting evaluation of the respective layouts.

The first case study involved populating empty positions (resulting from mortality of some ramets) in an existing European silver fir seed orchard. The original (remaining) clones were surrounded by ramets available from stock using 600 iterations of the ONA design. In the upgrading process, 46 empty positions were populated by 11 different clones. There were 39 clones of different representations (range: 3 to 9 ramets per clone) in the final scheme. This seed orchard was square-shaped, with spacing of 1:1, and it had 225 positions. The resulting scheme is depicted in Figure 1.

The second case study involved the establishment of a Douglas fir (Pseudotsuga menziesii (Mirb.) Franco) seed orchard with 666 positions with an asymmetrical layout. The orchard's parental population consisted of 23 clones, with two (\#21 and \#22) having a common single ancestor (parent). In the resulting scheme, these two related clones represented the main limiting factor (i.e., common ancestry), thus they were first deployed by the MI design in the form of five-tree clonal rows, with clones \#21 and \#22 represented by 7 and 6 rows respectively (arbitrarily selected). Subsequently, the other clones (\#1 to \#20) populated the remaining grid positions following the ONA design. Spatial optimization, assuming clonal rows, was performed based on the central position of each row, utilizing the original MI protocol [18]. Square layout was considered with 20 independent iterations of the MI scheme. This setting followed the methodology presented in [7]. In the resulting MI scheme, only clonal rows of related clones were initially placed, and other positions (601 positions) were populated by unrelated clones using the ONA (100 independent iterations), as shown in Figure 2.

The original ONA R code, which can be used for creating basic layouts, is available at: https://katedry.czu.cz/en/kgfld/software.

\section{Results and Discussion}

The layout depicted in Figure 1 displays the populating of empty positions in the existing European silver fir orchard (with added clones highlighted by white font). The Douglas fir resulting layout, shown in Figure 2, shows successful separation of the related clones (number 22 and 23) in clonal rows.

The qualities of the resulting schemes were assessed from the perspective of maximum panmixia using the parameter $\sigma_{\mathrm{min}}^{2}$, with values of 0.26 and 5.90 for the European Silver fir and Douglas fir, respectively. In the second case, the higher value of $\sigma_{\min }^{2}$ was caused by the presence of clonal rows.

In comparison, Chaloupková et al. [17] reported $\sigma_{\min }^{2}$ values equal to 0.24 and 3.85 for balanced and unbalanced clonal sizes, respectively. The parameter values are similar to the presented case studies, so this comparison shows the functionality of the ONA in these cases (upgrading existing orchards and ONA and MI merging), which are displayed here.

It is worth mentioning that ONA and MI designs have already been compared using the abovementioned parameters with random schemes and the COOL [7], as well as with the $\mathrm{R}^{2} \mathrm{SCR}$ design [17].

According to theoretical studies on clonally propagated reproductive material, the population size of 18 individuals should be reasonable and close to "optimal" to safeguard against potential unforeseen contingencies [19]. In an extensive review on the risks connected to clonal forestry, $\mathrm{Wu}(2018)$ [20] reports five to 30 clones as a reasonable number, depending on the species. Such population sizes are common for second-generation seed orchards. Therefore, advanced-generation seed orchards can also serve as both gene conservation and seed production units in some cases $[21,22]$. Several functional examples can be found for such instances in Swedish forestry [20]. However, these studies generally encompassed the random mating and other Hardy-Weinberg assumptions to achieve high genetic variation in forestry. One of the factors influencing the mating pattern in open pollination seed orchards (in addition to seed and pollen production, and reproduction phenology) is the orchard layout [3]. Therefore, the ONA is deemed as a suitable tool for promoting panmixia. 
There are additional factors which are detrimental to the genetic quality of seed orchard crop. These include, differences in clonal flowering phenology and fertility influencing the mating patterns and contributions of clones. Both of these factors were investigated in many field studies and are considered to be highly significant [23-25], and even software analyzing floral phenological synchronization in seed orchards was recently developed [26]. However, if the floral phenology is known, then it is possible to include the presumed flowering pattern as the input parameter in the MI design so that panmixia can be promoted during orchard design [7]. Another key factor is the pollen contamination occurrence, which increases the genetic diversity but also decreases the improvement effort efficiency. Molecular tools have been used to quantify the pollen contamination in many studies, and its value ranges from $30 \%$ to $40 \%$ [27] or it is even higher [28,29]. Unfortunately, the orchard design cannot be used for pollen contamination minimizing. It is known that the most effective method for its elimination/reduction is using greenhouses for maximum isolation, but another, less expensive method is the implementation of specific approaches directly to the breeding program. For example, the "Breeding without breeding" method can be used. In such a case, phenotypic preselection in progeny trials could lead to reduced contamination rates [30-33].

Figures, Tables, and Schemes

\begin{tabular}{|c|c|c|c|c|c|c|c|c|c|c|c|c|c|c|}
\hline 37 & 14 & 1 & 3 & 5 & 6 & 2 & 10 & 14 & 4 & 3 & 12 & 5 & 37 & 2 \\
\hline 2 & 39 & 4 & 12 & 11 & 9 & 15 & 37 & 39 & 13 & 22 & 1 & 6 & 11 & 14 \\
\hline 5 & 10 & 29 & 13 & 22 & 23 & 28 & 11 & 17 & 27 & 15 & 9 & 18 & 10 & 3 \\
\hline 3 & 6 & 18 & 27 & 24 & 16 & 14 & 6 & 14 & 24 & 5 & 3 & 31 & 9 & 39 \\
\hline 11 & 7 & 14 & 33 & 9 & 1 & 3 & 34 & 5 & 11 & 19 & 21 & 32 & 4 & 5 \\
\hline 32 & 9 & 21 & 34 & 39 & 25 & 15 & 36 & 26 & 2 & 25 & 34 & 9 & 13 & 1 \\
\hline 14 & 5 & 28 & 2 & 30 & 35 & 4 & 5 & 12 & 9 & 5 & 31 & 3 & 37 & 12 \\
\hline 37 & 2 & 16 & 24 & 13 & 26 & 14 & 15 & 6 & 38 & 10 & 18 & 16 & 22 & 6 \\
\hline 4 & 10 & 29 & 27 & 8 & 15 & 3 & 9 & 2 & 36 & 30 & 15 & 14 & 9 & 14 \\
\hline 1 & 18 & 33 & 19 & 31 & 37 & 38 & 20 & 26 & 25 & 39 & 19 & 35 & 11 & 2 \\
\hline 5 & 6 & 17 & 21 & 6 & 35 & 6 & 19 & 8 & 34 & 11 & 9 & 21 & 15 & 3 \\
\hline 39 & 13 & 7 & 15 & 16 & 34 & 11 & 21 & 1 & 16 & 5 & 27 & 2 & 10 & 4 \\
\hline 3 & 11 & 9 & 11 & 24 & 31 & 15 & 13 & 28 & 23 & 29 & 18 & 32 & 1 & 5 \\
\hline 2 & 12 & 10 & 4 & 29 & 18 & 39 & 12 & 7 & 4 & 9 & 35 & 6 & 39 & 37 \\
\hline 14 & 37 & 5 & 1 & 6 & 3 & 2 & 14 & 10 & 37 & 5 & 11 & 3 & 2 & 14 \\
\hline
\end{tabular}

Figure 1. Example of the Optimum Neighborhood Algorithm design for refilling empty positions in an existing orchard. Numbers designate individual clones' IDs. Numbers in white color represent refilled positions utilizing the ONA algorithm.

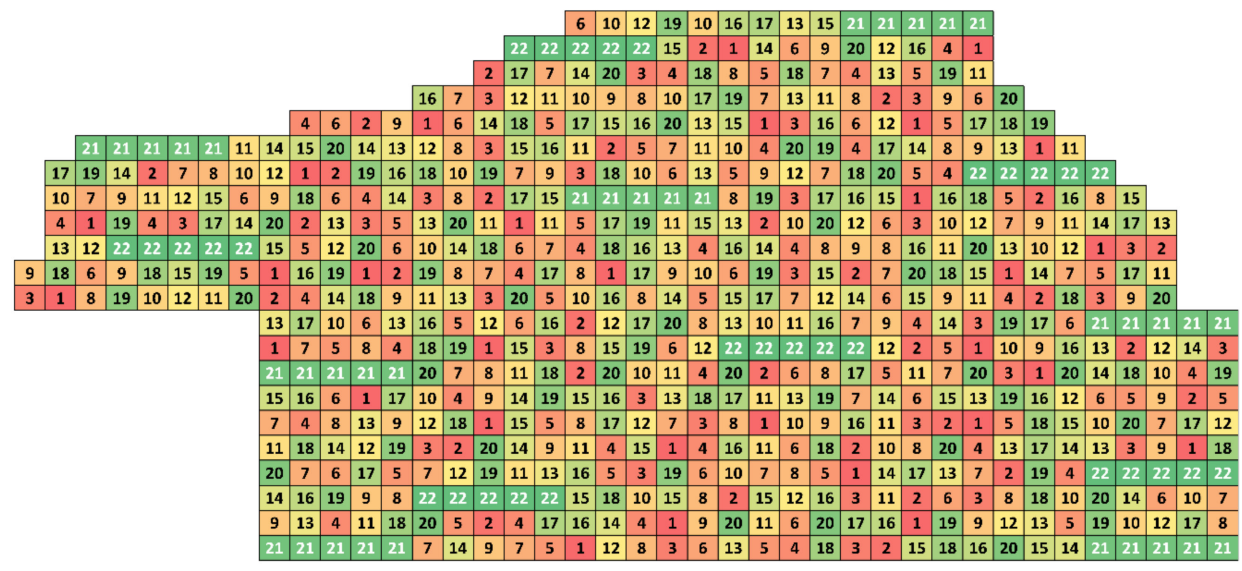

Figure 2. Design combining both Minimum Inbreeding and Optimum Neighborhood Algorithm designs. Numbers designate individual clones' IDs. Numbers in white color represent clonal rows utilizing MI algorithm. Remaining entries where optimized by ONA algorithm. 


\section{Conclusions}

The results show that the presented approach maintains all the advantages of both ONA and MI designs, and thus it is particularly suitable for establishing advanced-generations seed orchards. In addition to combining the advantages of the two designs, this new approach also eliminates the occurrence of the neighborhood effect. The influence of the neighborhood effect decreases when only the clones of the highest genetic gain are placed in clonal rows. These clones can be effectively managed for controlled pollination, which is also more easily applied within clonal rows as compared to orchards of regular layouts.

Equally interesting is the possibility of improving existing orchards by ONA, as demonstrated in the European Silver fir orchard, where ONA was effectively used for dealing with mortality of certain grafts. In a similar fashion, the same concept can be utilized for upgrading orchards after genetic thinning, where only high-value parents are retained and some positions may need to be populated.

Author Contributions: Conceptualization, K.C., M.L., and Y.A.E.-K.; methodology, K.C. and J.S.; software, K.C., M.L. and J.S.; validation, K.C. and J.S.; formal analysis, K.C.; investigation, K.C.; resources, K.C. and J.F.; data curation, K.C.; writing-original draft preparation, K.C. and J.S.; writing-review and editing, Y.A.E.-K., J.F.; visualization, K.C.; supervision, M.L.; project administration, K.C.; funding acquisition, K.C., J.S., and M.L.

Funding: Authors appreciate support from the Internal Grant Agency of Faculty of Forestry and Wood Sciences, Czech University of Life Sciences (IGA; grant A05/17), National Agency for Agriculture Research (NAZV; grant QJ1320013, QJ1620110), and “EXTEMIT-K", No. CZ.02.1.01/0.0/0.0/15_003/0000433 financed by OP RDE.

Conflicts of Interest: The authors declare no conflict of interest. The funders had no role in the design of the study; in the collection, analyses, or interpretation of data; in the writing of the manuscript, or in the decision to publish the results.

\section{References}

1. Zobel, B.J.; Barber, J.; Brown, C.L.; Perry, T.O. Seed orchards-Their concept and management. J. Forest. 1958, $56,815-825$.

2. Giertych, M. Seed orchard designs. For. Comm. Bull. 1975, 54, $25-37$.

3. White, T.L.; Adams, W.T.; Neale, D.B. Deployment-Open pollinated varieties full-sib families and clones. In Forest Genetics; CABI publishing: Wallingford Oxfordshire, UK, 2007; pp. 439-478.

4. Funda, T.; El-Kassaby, Y.A. Review: Seed orchards genetics. CAB Rev. 2012, 7, 13. [CrossRef]

5. Bell, G.D.; Fletcher, A.M. Computer organised orchard layouts (COOL) based on the permutated neighbourhood design concept. Silvae Genet. 1978, 27, 223-225.

6. Charkravarty, G.N.; Bagchi, S.K. Enhancement of the computer program of the permutated neighborhood seed orchard design. Silvae Genet. 1994, 43, 177-179.

7. Lstibůrek, M.; Stejskal, J.; Misevicius, A.; Korecký, J.; El-Kassaby, Y.A. Expansion of the minimum-inbreeding seed orchard design to operational scale. Tree Genet. Genomes 2015, 11, 12. [CrossRef]

8. El-Kassaby, Y.A. Clonal-row vs. random seed orchard designs: Mating pattern and seed yield of western hemlock (Tsuga heterophylla (Raf.) Sarg.). For. Genet. 2003, 10, 121-127.

9. El-Kassaby, Y.A.; Stoehr, M.U.; Reid, D.; Walsh, C.G.; Lee, T.E. Clonal-row vs. random seed orchard designs: Interior spruce mating system evaluation. Can. J. For. Res. 2007, 37, 690-696. [CrossRef]

10. El-Kassaby, Y.A.; Fayed, M.; Klápště, J.; Lstibůrek, M. Randomized, replicated, staggered clonal-row (R2SCR) seed orchard design. Tree Genet. Genomes 2014, 10, 555-563. [CrossRef]

11. Mitton, J.B. The dynamic mating systems of conifers. New Forest. 1992, 6, 197-216. [CrossRef]

12. El-Kassaby, Y.A. Evaluation of the tree improvement delivery system: Factors affecting the genetic potential. Tree Physiol. 1995, 15, 545-550. [CrossRef] [PubMed]

13. O'Connell, L.M. The Evolution of Inbreeding in Western Redcedar (Thuja plicata: Cupressaceae). Ph.D. Thesis, The University of British Columbia, Vancouver, BC, Canada, 2003.

14. Griffin, A.R.; Lindgren, D. Effect of inbreeding on production of filled seed in Pinus radiata experimental results and a model of gene action. Theor. Appl. Genet. 1985, 71, 334-343. [CrossRef] [PubMed]

15. Woods, J.H.; Heaman, J.C. Effect of different inbreeding levels on filled seed production in Douglas-fir. Can. J. For. Res. 1989, 19, 54-59. [CrossRef] 
16. Williams, C.G.; Savolainen, O. Inbreeding depression in conifers: Implications for breeding strategy. For. Sci. 1996, 42, 102-117.

17. Chaloupková, K.; Stejskal, J.; El-Kassaby, Y.A.; Lstibůrek, M. Optimum neighborhood seed orchard design. Tree Genet. Genomes 2016, 12, 105. [CrossRef]

18. Lstibůrek, M.; El-Kassaby, Y.A. Minimum-inbreeding seed orchard design. For. Sci. 2010, 56, $603-608$.

19. Yanchuk, A.D.; Bishir, J.W.; Russel, J.H.; Polsson, K.R. Variation in volume production through clonal deployment: Results from a simulation model to minimize risk for both a currently known and unknown future pest. Silvae Genet. 2006, 55, 25-37. [CrossRef]

20. Wu, H.X. Benefits and risk of using clones in forestry-A review. Scan. J. For. Res. 2018, 33. [CrossRef]

21. Namkoong, G.; Kang, H.C.; Brouard, J.S. Provenance testing, ecogeographic surveys, and conservation. In Tree Breeding: Principles and Strategies; Springer: New York, NY, USA, 1988; pp. 132-159.

22. Frankel, O.H.; Brown, A.H.D.; Burdon, J.J. The Conservation of Plant Biodiversity; Cambridge University: Cambridge, UK, 1995.

23. Erickson, V.J.; Adams, W.T. Mating success in a coastal Douglas-fir seed orchard as affected by distance and floral phenology. Can. J. For. Res. 1989, 19, 1248-1255. [CrossRef]

24. El-Kassaby, Y.A.; Reynolds, S. Reproductive phenology, parental balance, and supplemental mass pollination in a sitka-spruce seed-orchard. Forest Ecol. Manag. 1990, 31, 1-2. [CrossRef]

25. Nikkanen, T. Reproductive phenology in a Norway spruce seed orchard. Silva Fenn. 2001, 35, 39-53. [CrossRef]

26. Zas, A.R.; Merlo, E.; Fernández, L.J. SYNCHRO: A SAS program for analysing the floral phenological synchronisation in seed orchards. Silvae Genet. 2003, 52, 212-215.

27. Slavov, G.T.; Howe, G.T.; Adams, W.T. Pollen contamination and mating patterns in a Douglas-fir seed orchard as measured by simple sequence repeat markers. Can. J. For. Res. 2005, 35, 1592-1603. [CrossRef]

28. Torimaru, T.; Wang, X.R.; Fries, A.; Anderson, B.; Lindgren, D. Evaluation of pollen contamination in an advanced Scots pine seed orchard. Silvae Genet. 2009, 58, 262-269. [CrossRef]

29. Pakkanen, A.; Nikkanen, T.; Pulkkinen, P. Annual variation in pollen contamination and outcrossing in a Picea abies seed orchard. Scan. J. For. Res. 2000, 15, 399-404. [CrossRef]

30. El-Kassaby, Y.A.; Lstibůrek, M. Breeding without breeding. Genet. Res. 2009, 91, 111-120. [CrossRef] [PubMed]

31. Lstibůrek, M.; Klápště, J.; Kobliha, J.; El-Kassaby, Y.A. Breeding without breeding: Effect of gene flow on fingerprinting effort. Tree Genet. Genomes 2012, 8, 873-877. [CrossRef]

32. Lstibůrek, M.; Ivanková, K.; Kadlec, J.; Kobliha, J.; Klápště, J.; El-Kassaby, Y.A. Breeding without breeding: Minimum fingerprinting effort with respect to the effective population size. Tree Genet. Genomes 2011, 7, 1069-1078. [CrossRef]

33. Lstibůrek, M.; Hodge, G.R.; Lachout, P. Uncovering genetic information from commercial forest plantations-Making up for lost time using "breeding without breeding". Tree Genet. Genomes 2015, 11, 55. [CrossRef]

(C) 2019 by the authors. Licensee MDPI, Basel, Switzerland. This article is an open access article distributed under the terms and conditions of the Creative Commons Attribution (CC BY) license (http://creativecommons.org/licenses/by/4.0/). 